Archives of Virology 50, 237-240 (1976)

(C) by Springer-Verlag 1976

\title{
Aride Virus, a New Ungrouped Arbovirus Infecting Amblyomma Loculosum Ticks from Roseate Terns in the Seychelles*
}

\author{
Brief Report
}

\author{
By

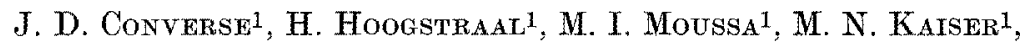 \\ J. CASALS ${ }^{2}$, and C. J. Feare ${ }^{3}$ \\ 1 United States Naval Medical Research Unit Number Three (NAMRL-3), \\ American Embassy, Cairo, Arab Republic of Egypt \\ 2 Yale Arbovirus Research Unit (YARU), Yale University School of Medicine, \\ New Haven, Connecticut U.S.A. \\ ${ }^{3}$ Ministry of Agriculture, Fisheries and Food Pest Infestation Control Laboratory, \\ Tangleyplace, Worplesdon, Guildford, Surrey, England
}

Accepted October 15, 1975

\section{Summary}

A previously undescribed arbovirus, proposed name Aride virus, was recovered from Amblyomma loculosum Neumann, collected from dead roseate terns Sterna dougallii arideensis Mathews in the Seychelles. Some important tick-virus-host associations are discussed.

Irregularities in flights of marine birds, owing to injury, illness, or exhaustion, may be an important factor in the geographic distribution of certain arboviruses and tick parasites, some of which cause human illness (3). The exceptionally wide distribution of hard and soft ticks and their numerous host species, and the fact that humans visiting bird breeding colony areas are bitten and may become infected by virus infected ticks, emphasize the importance of studies on the identification and characterization of previously unknown, or suspected new viral agents.

* From Research Projects MF 51.524.009-3022B and -0055, Naval Medical Research and Development Command, Department of the Navy, Washington, D.C. The opinions and assertions contained herein are the private ones of the authors and are not to be construed as official or as reflecting the views of the Department of the Navy or of the naval service at large.

The field work was supported by a Natural Environment Research Council Research Fellowship at the University of Aberdeen Scotland, and in part by NAMRU-3. 
Herein we report the recovery of an apparently new arbovirus infecting the hard tick Amblyomma loculosum Neumann, which infests marine birds in the Seychelles, Indian Ocean. A. loculosum is recorded from 14 species and subspecies of marine birds from the Indian Ocean (Tanzania and islands in the Seychelles, Mauritius, and Cocos Keeling groups), and from islands in the Coral Sea off Queensland and near New Caledonia and in the Caroline Group in the Pacific Ocean (4). People visiting infested localities are frequently bitten by $A$. loculosum.

Three female A. loculosum were collected on 8 July 1973 by C. J. Feare from the feet of the 2 freshly dead roseate terns on Bird Island in the Seychelles, about 40 miles from Aride Island where numerous roseate terns breed. The collector was investigating a dieoff of thousands of sooty terns, Sterna fuscata nubilosa Sparmann, associated with a high population density of another tick species, Ornithodoros (Alectorobius) capensis Neumann, infected by Soldado virus of the Hughes serogroup (2).

Two of the 3 A. loculosum (HH37, 435) from the dead roseate terns were placed in a single pool and inoculated into 2 suckling white mice families. The third A. loculosum was preserved for taxonomic studies.

The virus recovery methods, virus characterization [filtration, sodium deoxycholate (SDC) sensitivity], serological procedures [hemagglutinin (HA), complementfixation (CF), and neutralization (NT) tests], experimental infection in laboratory animals and neutralization index (NI) calculations were as described earlier (1).

A virus strain (EgArt 3088) was recovered and reisolated 9 months later from the original tick suspension. Primary virus passage in mice was variable, with 5 of 14 mice sick by day 8 (range 4 to 8 days). Second and third infected mouse brain (IMB) passage caused illness and paralysis in all 14 mice by day 4 . Sixth passage IMB suspension log $\mathrm{LD}_{50}$ (50 per cent lethal dose) was $10^{3.5} / \mathrm{ml}$ intracerebrally (i.c.) and $10^{2.0} / \mathrm{ml}$ intraperitoneally (i.p.); the average survival time was 5 days. The ICLD 50 titer following filtration through 0.45 and $0.22 \mu$ millipore membrane filter was $10^{3.0}$ and $10^{1.2} / \mathrm{ml}$, respectively. In other studies EgArt 3088 demonstrated SDC sensitivity, i.e., $4.5 \mathrm{log}$ reduction in titer.

In CF screen tests at NAMRU-3 and at YARU, using reference monovalent and polyvalent hyperimmune mouse sera to known arboviruses (Table 1), no serological relationship was established with any known arbovirus group, including Soldado virus, which was isolated from other ticks in the Seychelles (2). HA tests with sucrose-acetone extracted antigen of EgArt 3088 and goose erythrocytes at $\mathrm{pH}$ ranges $5.8-7.2$ and $4^{\circ}$ and $37^{\circ} \mathrm{C}$ were also negative.

Sixth passage IMB suspension caused paralysis and death in suckling mice by both i.c. and i.p. inoculation routes, but not in suckling hamsters, guinea pigs or rabbits. CF antibody production to EgArt 3088 virus was demonstrated in hamster and rabbit sera $(1: 4$ and $1: 32$, respectively). No cytopathological reaction or virus multiplication were demonstrated in chick embryo fibroblast, Vero, BHK-21, embryonic hamster, or HeLa cell cultures using ten-fold dilutions $\left(10^{2}\right.$ to $10^{8}$ ) of EgArt 3088 virus IMB suspensions.

Virus isolate EgArt 3088 appears to be a previously undescribed, ungrouped arbovirus. The dead roseate terns carrying the infected ticks probably became infested and apparently infected in their breeding grounds on Aride Island. We propose the name Aride virus for this agent. 
Table 1. Reference virus-immune serum tested by complement-fixation with Aride virus EgArt 3088 at NAMRU-3 and YARU

\begin{tabular}{ll}
\hline Abu Hammad (EgArt 1194) & Pathum Thani (EgArt 753) \\
Abu Mina (EgArt 4996-63) & Powassan \\
Acado (Ar 1846-64) & Pretoria (EgArt 3089) \\
Arumowot (Ar 1284-64) & Punta Salinas (CalAr 888) \\
Bahig (EgAnB 90) & Qalyub (EgArt 237) \\
Bandia (IPD/A) & Quaranfil (EgArt 1113) \\
Bhanja (Ig 690) & Royal Farm (EgArt 371) \\
Bunyamwera & Sakhalin (56300.86) \\
Burg El Arab (An 3782-62) & Sandfly Fever (H5202) \\
Chenuda (EgArt 1152) & Sandfly Fever (AR 443-61) \\
Chobar Gorge (707100-8) & Sawgrass (Ta 14-64A-1247) \\
Colorado Tick Fever (Condon) & Silverwater (M 3737) \\
Congo (Ug 3010) & Simbu (An 6165-31) \\
Dengue-1 & Sindbis (Original) \\
Dera Ghazi Khan (JD 254) & Soldado (Tr 52214) \\
Dhori (Ig 61-1313, EgArt 930) & Thogoto (EgArt 734) \\
Dugbe (IgAr 1792) & Tribev (Original) \\
Farallon (CalAr 846) & Uganda S \\
Ganjam (Ig 619) & Upolu (C 5581) \\
Grand Arbaud (EgArt 363) & Uukuniemi (An 1825-61) \\
Hazara (JC 280) & Wad Medani (EgArt 492) \\
Huacho (CalAr 883) & Wanowrie (Ig 700, EgArt 865) \\
Hughes (Dry Tortugas) & West Nile (Eg 101) \\
Johnston Atoll (LBJ) & Yellow Fever (17D) \\
Jos (IbAr 17854) & Zika \\
Kaisodi (G 14132) & Zirqa (Por 7866, HRT 619) \\
Kao Shuan (EgArt 904) & Q3255 \\
Kemerovo (EgAn 1169-61) & EgArt 427 \\
Keterah (Hooper 1361) & EgArt 1147 \\
Lagos Bat & EgArt 1475 \\
Langat (TP 21) & EgArt 2771 \\
Lanjan (TP 94) & EgArt 3080 \\
Lipovnik (Lip 91) & EgArt 3091 \\
Lone Star (TM 1381) & EgArt 3608 \\
Manawa (PakAr 462) & EgArt 3716 \\
Matariya (EgAn 1477-61) & EgAr 1169-64 \\
Matruh (EgAn 1047-61) & EgAr 1225-64 \\
Matucare (Maru 21343) & EgAnB 12502 \\
Mono Lake (CalAr 861) & EgAnB 13383 \\
Nyamanini (EgArt 1304) & EgAnB 1398-61 \\
Obodhiang (Ar 1275-64) & \\
&
\end{tabular}

Aride virus is ecologically associated with marine birds and ticks occupying restricted habitats where birds breed or rest and virus circulation may be seasonal or continue throughout the year (3). Presently there is no proof of transstadial or transovarial transmission of Aride virus in A. loculosum, nor that other species of marine birds are susceptible. Antibody to Aride virus has yet to be demonstrated in the marine birds or humans.

It is noteworthy that Aride virus, characterized here, was isolated from fully fed female ticks taken from the feet of 2 dead roseate terns, Sterna dougallii arideensis Mathews, in full adult breeding plumage, on an island about 40 miles from the nearest breeding colony. The fed ticks were capable of ovipositing, and 
larvae hatching where the terns fell might easily have found new hosts among the tens of thousands of other marine birds nesting nearby. Some of the frequently documented but usually unexplained deaths of numerous marine birds in many parts of the world may be caused by poorly-known arbovirus infections. The number of reports of Amblyomma loculosum attacking humans on islands in the Indian and Pacific oceans and in the Coral Sea (4) enhance interest in the epidemiology of Aride virus.

The lack of knowledge of the ecology and infectivity of Aride virus indicates the need for further work to establish the importance of this agent and its epidemiology in nature.

\section{Acknowledgments}

The technical assistance of A. F. El Mour, R. H. G. Roushdy and S. Gaber is gratefully acknowledged.

\section{References}

1. Converse, J. D., Hoogstraal, H., Moussa, M. I., Stek, M., JR., Kaiser, M. N.: Bahig virus (Tete Group) in naturally- and transovarially-infected Hyalomma marginatum ticks from Egypt and Italy. Arch. ges. Virusforsch. 46, 29-35 (1974).

2. Converse, J. D., Hoogstraal, H., Moussa, M. I., Feare, C. J., Katser, M. N.: Soldado virus (Hughes Group) from Ornithodoros (Alectorobius) capensis (Ixodoidea: Argasidae) infesting sooty term colonies in the Seychelles, Indian Ocean. Amer. J. trop. Med. Hyg, 24, 1010-1018 (1975).

3. Hoogstrane, H.: Viruses and tioks. In: Gibbs, A. J., (ed.), Viruses and Invertebrates, Chap. 18, 349-390. Amsterdam: North Holland Publishing Co. 1973.

4. Hoogstraal, H., Wassef, H. Y., Converse, J. D., Keirans, J. E., Clifford, C. M., Feare, C. J.: Amblyomma loculosum (Ixodoidae: Ixodidae): Identy, marine bird and human hosts, virus infection, and distribution in the Southern Oceans. Ann. Entomol. Soc. Amer. (in press).

Authors' address: Dr. J.D. Convarse, NAMRU-3, FPO, New York, NY 09527, U.S.A.

Received August 29, 1975 